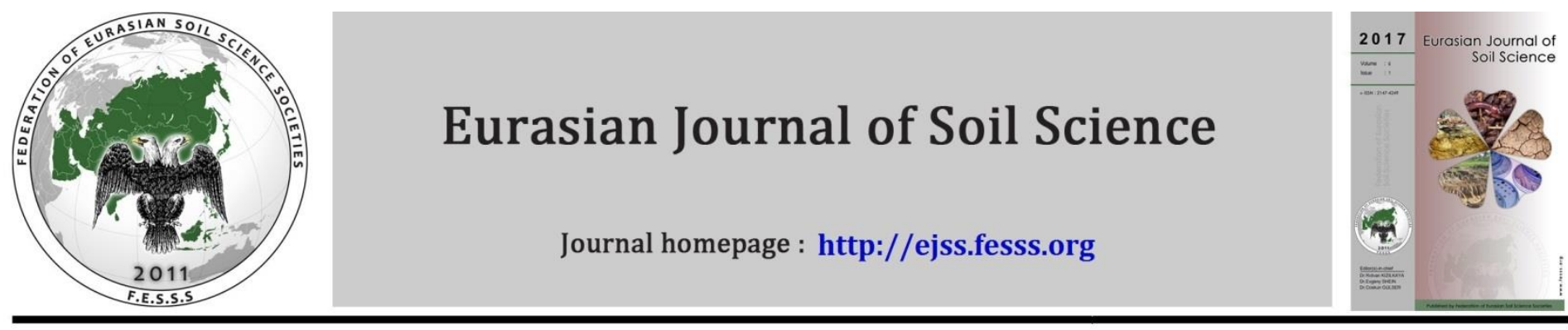

\title{
Using microbiological leaching method to remove heavy metals from sludge
}

\author{
Zhuyu Gu a, Yilahong Aikebaier a, Valeria Arefieva b,*, Mikhail Mazirov b \\ a Xinjiang Key Laboratory of Soil and Plant Ecological Processes, College of Grassland and Environmental Sciences, \\ Xinjiang Agricultural University, Urumqi, China. \\ b Department of Soil Management and Experimental Design, Russian State Agrarian University - Moscow Timiryazev \\ Agricultural Academy, Moscow, Russia
}

\section{Article Info}

Received : 13.05 .2016

Accepted : 11.07.2016

\begin{abstract}
Microbial leaching is one of the most effective methods to remove heavy metals from sludge. In the conducted researches, the sludge samples were processed with Thiobacillus ferrooxidans and Thiobacillus thiooxidans obtained via cultivation, extraction and purification processes. Heavy metals such as $\mathrm{Pb}, \mathrm{Cd}, \mathrm{Cu}$ and $\mathrm{Ni}$ were leached from sludge by Thiobacillus ferrooxidans and Thiobacillus thiooxidans within different substrate concentration and $\mathrm{pH}$ value conditions. It is defined that from the point of view of economy and efficiency the optimal concentration of $\mathrm{FeSO}_{4} \cdot 7 \mathrm{H}_{2} \mathrm{O}$ and sulfur for bio-leaching process was $0.2 \mathrm{~g}$. The leaching rates of heavy metals such as $\mathrm{Pb}$, $\mathrm{Cd}, \mathrm{Cu}$ and $\mathrm{Ni}$ of the same concentration were $74.72 \%, 81.54 \%, 70.46 \%$ and $77.35 \%$ respectively. However, no significant differences depending on the $\mathrm{pH}$ value among the leaching rates were defined, even for the $\mathrm{pH}$ value of 1.5. Along with the removal of heavy metals from sludge, the organic matter, N, P, K were also leached to some extent. The losing rate of phosphorus was the highest and reached $38.44 \%$. However, the content of organic matter, N, P, K in the processed sludge were higher in comparison with level I of the National Soil Quality Standards of China. Ecological risk of heavy metals in sludge before and after leaching was assessed by Index of Geo-accumulation (Igeo) and comprehensive potential risk (RI). The results of research defined that the content of heavy metals in sludge meets the level of low ecological risk after leaching and their contents is lower in comparison with the National Agricultural Sludge Standard of China. Sludge leached by biological methods is possible to use for treatment for increasing soil fertility.
\end{abstract}

Keywords: $\mathrm{pH}$ value, sludge, microbiological leaching, substrate concentration, heavy metals.

(C) 2017 Federation of Eurasian Soil Science Societies. All rights reserved

\section{Introduction}

Urban sewage and industrial wasted water became one of the main ecological problems in cities of China, along with the growing economy and expanding population. Therefore, proper sanitization of sewage sludge is a critical task for wasted water plants. Sludge contains large quantity of nutrient substance such as organic matter, nitrogen, phosphorus and potassium. 50-80\% heavy metals in sewage sludge (Lester et al., 1983; Brown et al., 1979) discharged from wasted water without proper disposal is the main secondary pollutant

\footnotetext{
${ }^{*}$ Corresponding author.

Department of Soil Management and Experimental Design, Russian State Agrarian University - Moscow Timiryazev Agricultural Academy, Timiryazevskaya Str., 49, Moscow, 127550, Russia

Tel.: +74999761642

e-ISSN: $2147-4249$ 
source of the environment. Currently, the mostly applied methods used in wasted water plants in China were incineration, throwing to sea, landfill and land application (Wang et al., 2014; Liu, 2014). The land application has been considered as the most efficient disposal method in the future, as it brought positive inclinations in the soil-plant-sewage-sludge system. However, heavy metals in sludge provide environmental risk with their poisonous, long-latency and accumulative characteristics (Dai et al., 2012; Shen et al., 2007). Chemical, electro-chemical and bio-leaching methods are widely used in removing heavy metals in sludge (Jakobsen et al., 2004; Shi et al., 2013; Babel et al., 2006). Bio-leaching is mostly implemented due to low acid waste utilization and high extract efficiency (Pathak et al., 2009a).

Bio-leaching is the method based on extracting heavy metals in infusible solid form by using functions of natural micro-organism such as oxidation, reduction, complexion and dissolution (Pathak et al., 2009b; Peng et al., 2011; Zhu et al., 2013). Heavy metals in liquid wasted water are usually removed by chemical and electrochemical methods (Kaminari et al., 2007; Hunsom et al., 2005). Thiobacillus ferrooxidans and Thiobacillus thiooxidans are the common micro-organisms used in bio-leaching methods. Those bacteria in $\mathrm{FeSO}_{4} \cdot 7 \mathrm{H}_{2} \mathrm{O}$ and sulfur substrates perform well in removing heavy metals in sludge and their implementing is not expensive (Sreekrishnan and Tyagi, 1996). The majority of studies on bio-leaching of heavy metals in sludge focused only on the removal efficiency, but the nutrient matters questions in sludge were often omitted. The aim of our researches is to define changing in the nutrient matters under the bio-leaching of heavy metals in sludge with Thiobacillus ferrooxidans (T.f.) and Thiobacillus thiooxidans (T.t.), and decide the appropriate substrate $\left(\mathrm{FeSO}_{4} \cdot 7 \mathrm{H}_{2} \mathrm{O}\right.$ and sulfur) condition and $\mathrm{pH}$ value suitable for maintaining nutrients content and removing heavy metals.

\section{Material and Methods}

\section{Sample collection and treatment}

Sludge samples were isolated form the Hedong wasted water treatment plant in Urumqi in May, 2014. Sewage contains in average $15 \mathrm{~g} \mathrm{~L}^{-1}$ sludge. After air drying sludge was pulverized with mortar and pestle after and separated with 100 mesh sieve. Powder sample was stored in fridge at $4^{\circ} \mathrm{C}$ in plastic bottle. Physical and chemical properties of sludge were measured with standard methods (Pansu et al., 2006).

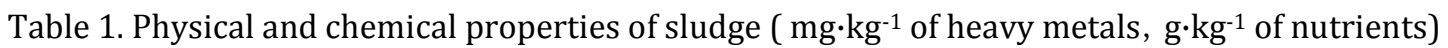

\begin{tabular}{|c|c|c|c|c|c|c|c|c|}
\hline Sample & $\mathrm{Pb}$ & $\mathrm{Cd}$ & $\mathrm{Cu}$ & $\mathrm{Ni}$ & $\begin{array}{l}\text { Organic } \\
\text { Matter }\end{array}$ & $\mathrm{N}_{\text {total }}$ & $\mathrm{P}_{\text {total }}$ & $\mathrm{K}_{\text {total }}$ \\
\hline Sludge & 45.00 & 8.00 & 95.57 & 158.35 & 435.61 & 11.49 & 13.24 & 4.8 \\
\hline $\begin{array}{l}\text { National Agricultural Sludge Quality } \\
\text { Standard of China } \mathrm{pH}<6.5\end{array}$ & 300 & 5 & 250 & 100 & - & - & - & - \\
\hline $\begin{array}{l}\text { National Agricultural Sludge Quality } \\
\text { Standard of China GB4282-84 } \mathrm{pH} \geq 6.5\end{array}$ & 1000 & 20 & 500 & 200 & - & - & - & - \\
\hline
\end{tabular}

\section{Source and cultivation of microorganisms}

Thiobacillus strains were obtained from sewer mud in the campus of Xinjiang Agricultural University in Urumqi, and some mud samples were stored in sterile water.

\section{Thiobacillus ferrooxidans (T.f.) cultivation}

$10 \mathrm{~mL}$ bacteria sample was placed in Erlenmeyer flasks, that contained $100 \mathrm{ml} 9 \mathrm{k}$ standard growth medium, and the medium was incubated at $30{ }^{\circ} \mathrm{C}$ and $160 \mathrm{rpm} \mathrm{min}^{-1}$ for 5 days. Clear part was extracted from red brown liquid and incubated repeatedly, then separated and purified in $9 \mathrm{k}$ solid medium. Reddish colony appeared in $9 \mathrm{k}$ solid medium after 7 days. Selected colony was expanded in liquid medium to get T.f. bacteria (Lombardi et al., 2002).

\section{Thiobacillus thiooxidans (T.t.) cultivation}

$10 \mathrm{~mL}$ bacteria sample was incubated in an Erlenmeyer flask containing $100 \mathrm{ml}$ of the Starkey-S medium at $30{ }^{\circ} \mathrm{C}$ and $160 \mathrm{rpm} \mathrm{min}^{-1}$. The medium became turbid and elemental sulfur precipitated that causes the decline of pH (about 1) after 7-10 days. Then bacteria was separated and purified in sodium thiosulfate culture medium. Then after 6 days, white colony that appeared in medium was selected to amplify in Starkey-S culture medium, and quite pure T.t was obtained (González et al., 1995). 


\section{Heavy metal leaching methods for different substrates}

1. Bio-leaching of sludge with different substrates: $0.4 \mathrm{~g}$ sulfur, $5 \mathrm{~mL}$ T.t. and $5 \mathrm{~mL}$ T.f. were added into 150 $\mathrm{mL}$ sludge in $300 \mathrm{ml}$ Erlenmeyer flask, then $0.1,0.2,0.3$, and $0.4 \mathrm{~g}$ of $\mathrm{FeSO}_{4} \cdot 7 \mathrm{H}_{2} \mathrm{O}$ were added to maintain $\mathrm{pH}$ of 6.0.

2. Bio-leaching of sludge with different sulfur treatments: $\mathrm{FeSO}_{4} \cdot 7 \mathrm{H}_{2} \mathrm{O}$ with optimal concentration obtained by method (1) , $5 \mathrm{~mL}$ T.t. and $5 \mathrm{~mL}$ T.f. were added to $150 \mathrm{~mL}$ sludge in $300 \mathrm{~mL}$ flask. The pH values of each solution were about 6.0 and $0.1,0.2,0.3$, and $0.4 \mathrm{~g}$ and sulfur powder were added into the solutions.

3. Solution of the optimal substrate concentration obtained by method (2) was divided into four groups with $\mathrm{pH}$ values of $6.0,5.0,4.0,3.0$, and 2.0 before cultivation. Each substrate was performed in three replications and incubated in the rotatory shaker apparatus at $160 \mathrm{rpm} \mathrm{min}^{-1}$ and $30{ }^{\circ} \mathrm{C}$ for 10 days. The water lost with evaporation during the cultivation period was supplemented with sterile water.

\section{Analysis methods}

The $\mathrm{pH}$ values of the solution were measured with pHS-3C pH meter every day. Sludge in heating oven was dissolved with aqua regia $+\mathrm{HClO}_{4}$, then rinsed with $0.1 \mathrm{~mol} \mathrm{~L}^{-1} \mathrm{HCl}$ before filtration and diluted to constant volume. Heavy metal content was measured with atomic adsorption spectrometry (TAS 990, Pgeneral Beijing). Chemical compounds of heavy metals before and after leaching were analyzed with Tessier sequential extraction method (Tessier et al., 1979) for assessment of potential ecological risk. Total content of nitrogen, phosphorus, potassium and organic matter were measured with standard methods (Pansu et al., 2006).

\section{Assessment methods}

Two methods were used to assess the heavy metal pollution caused by sludge application.

(1) Indexes of geoaccumulation (Muller, 1969) were used to assess the value of the pollution level and the value of level I (GB15618-1995) that was taken as the background for assessment. Assessment formula:

$$
I_{\text {geo }}=\log _{2}\left(C_{n} / 1.5 B_{n}\right)
$$

$\mathrm{C}_{\mathrm{n}}$ - concentration of the metal pollutant (mg.kg-1);

$\mathrm{Bn}$ - geochemical background concentration of the pollutant in sediment (mg.kg-1)

1.5 - background matrix correction factor caused by lithogenic effect.

$I_{\text {geo }}$ consists of seven grades ranging from unpolluted to very highly polluted (Table 2).

Table 2. Indexes of geo-accumulation and RI and the pollution grades of heavy metal

\begin{tabular}{|c|c|c|c|c|c|c|}
\hline \multicolumn{3}{|c|}{ Index of geo-accumulation } & \multicolumn{4}{|c|}{ Potential ecological risk index } \\
\hline $\mathrm{I}_{\text {geo }}$ & Grade & Assessment & single metal 1 & k factor grade & Integrat & RI grade \\
\hline 0 & 0 & Uncontaminated & & & & \\
\hline $0-1$ & 1 & $\begin{array}{l}\text { Uncontaminated to } \\
\text { moderately contaminated }\end{array}$ & $\mathrm{Ei} \leq 40$ & I low & $\mathrm{RI} \leq 150$ & A low \\
\hline $1-2$ & 2 & Moderately contaminated & & & & \\
\hline $2-3$ & 3 & $\begin{array}{l}\text { Moderately contaminated to } \\
\text { highly contaminated }\end{array}$ & $40<\mathrm{E}_{\mathrm{i}} \leq 80$ & II middle & $150<\mathrm{RI} \leq 300$ & B middle \\
\hline $3-4$ & 4 & Highly contaminated & $80<E_{i} \leq 160$ & III appreciable & $300<\mathrm{RI} \leq 600$ & C appreciable \\
\hline $4-5$ & 5 & $\begin{array}{l}\text { Highly to very highly } \\
\text { contaminated }\end{array}$ & $160<\mathrm{E}_{\mathrm{i}} \leq 320$ & IV high & $\mathrm{RI}>600$ & D high \\
\hline$>5$ & 6 & Very highly contaminated & $E_{i}>320$ & V much high & & \\
\hline
\end{tabular}

(2) Potential ecological risk index (Yu et al., 2010)

RI method assesses the pollution by toxicity coefficients of a single and multiple metal pollutants. The index is represented as:

$$
\begin{array}{r}
\mathrm{E}_{\mathrm{i}}=\mathrm{T}_{\mathrm{i}} \times \mathrm{C}_{\mathrm{n}} / \mathrm{B}_{\mathrm{n}} \\
\mathrm{RI}=\sum^{2} \mathrm{E}_{\mathrm{i}}
\end{array}
$$

Both $C_{n}$ and $B_{n}$ were identical to formula (1);

$\mathrm{E}_{\mathrm{i}}$ - potential ecological risk index of metal i ;

$\mathrm{T}_{\mathrm{i}}$ - toxicity coefficients of $\mathrm{Pb}, \mathrm{Cd}, \mathrm{Cu}$, and $\mathrm{Ni}$ are 5, 30, 5, and 5, respectively (Hakanson, 1980; Liu et al., 2014). The pollution level graded by $E_{\mathrm{i}}$ and RI is shown in Table 2. 


\section{Results and Discussion}

\section{Impact of $\mathrm{FeSO}_{4}$ concentration on the efficiency of bio-leaching}

Two strains of Thiobacillus oxidized $\mathrm{Fe}^{2+}$ and sulfur to $\mathrm{Fe}^{3+}$ and sulfuric acid. In the result, $\mathrm{pH}$ slightly decreased (Chao et al., 2008). At the beginning, T.f. populated massively, $\mathrm{H}^{+}$was generated during the oxidation of $\mathrm{Fe}^{2+}$ to $\mathrm{Fe}^{3+}$. When $\mathrm{pH}$ declined to 4, T.f. began to propagate and oxidized elemental sulfur to sulfuric acid. Finally pH declined to about 1.5 (Wang, 2004).

During the first 2 days, pH value rose slightly and reached to 6.51, and then $\mathrm{pH}$ value declined. This result defined that the bacteria need about 2 days to start their propagation. After 8 days, $\mathrm{pH}$ value in variants with

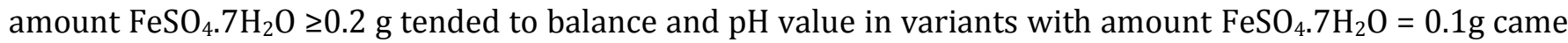
to balance in 10 days. At the 8th day, $\mathrm{pH}$ values of the solution were 2.42, 1.61, 1.52, and 1.43, respectively. Overall, increasing the $\mathrm{FeSO}_{4} .7 \mathrm{H}_{2} \mathrm{O}$ amount forced acid generating in solution and the earlier balance of the oxidation process. After 10 days the reaction stopped (Figure 1).

The leaching of mixed bacteria was quite inefficient while treatment with $0.1 \mathrm{~g} \mathrm{FeSO}_{4} .7 \mathrm{H}_{2} \mathrm{O}$ and began to be efficient with $0.2 \mathrm{~g} \mathrm{FeSO}_{4} .7 \mathrm{H}_{2} \mathrm{O}$. The leaching rate of $\mathrm{Pb}, \mathrm{Cd}, \mathrm{Cu}$ and $\mathrm{Ni}$ were $76.53 \%, 80.54 \%, 72.10 \%$, and $75.38 \%$, respectively. The leaching effect became significant in case $\mathrm{FeSO}_{4} 7 \mathrm{H}_{2} \mathrm{O}$ amount exceeded $0.2 \mathrm{~g}$ and the minimum amount of $\mathrm{FeSO}_{4} .7 \mathrm{H}_{2} \mathrm{O}$ in bio-leaching must be $0.2 \mathrm{~g}$. The growth of T.f. was suppressed by the rising of $\mathrm{Fe}^{3+}$ concentration (Zhou et al., 2002) that prevented leaching. In case of industrial application the concentration of iron compound has to be maintaining at the level of about $5 \%$ (Shen et al., 2005) for enhancing the leaching efficiency (Figure 2).

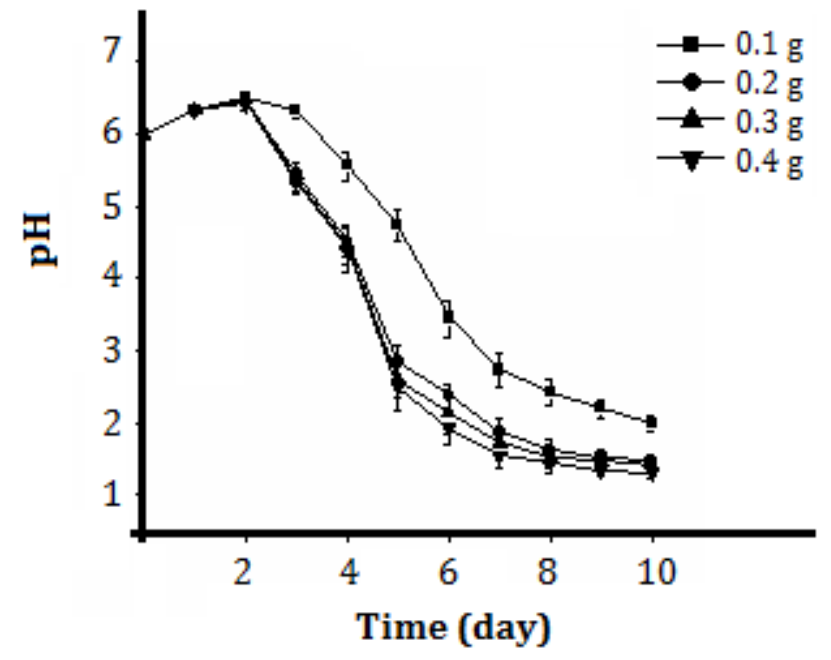

Figure 1. Effect of $\mathrm{FeSO}_{4} .7 \mathrm{H}_{2} \mathrm{O}$ implementing on $\mathrm{pH}$ of leaching solutions

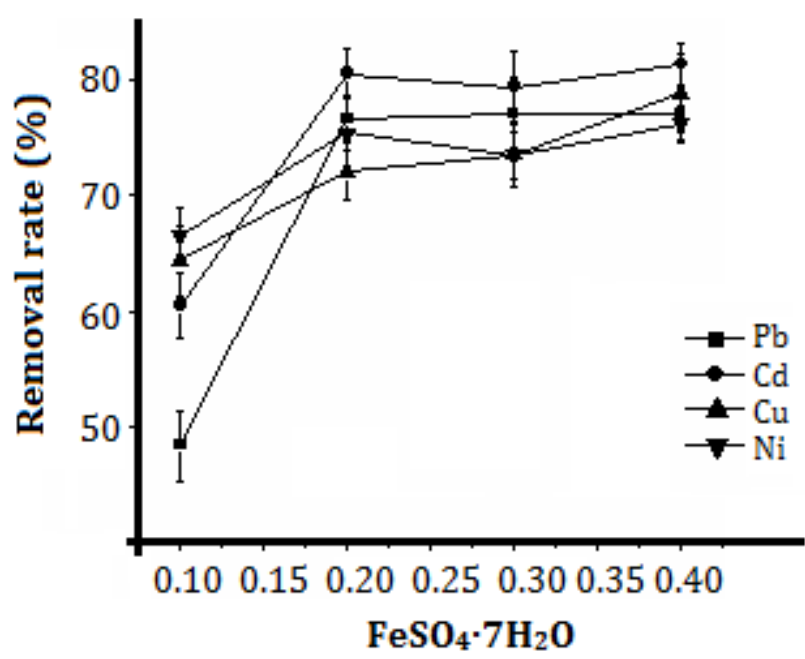

Figure 2. Effect of $\mathrm{FeSO}_{4} \cdot 7 \mathrm{H}_{2} \mathrm{O}$ concentration on the leaching efficiency of heavy metals

\section{Effect of sulfur concentration on the leaching efficiency of mixed bacteria}

Changing the $\mathrm{pH}$ value of leaching solution under different sulfur concentrations along with the same $\mathrm{FeSO}_{4 .} .7 \mathrm{H}_{2} \mathrm{O}$ amount $(0.2 \mathrm{~g}$ ) is defined (Figure 3). During the first 2 days, the $\mathrm{pH}$ value increased slightly and reached the maximum value of 6.79 at the end of the second day. Then $\mathrm{pH}$ began to decrease significantly along with the increment of sulfur concentration. It is explained by influence of sulfur content on bacteria propagation. The acidity became higher along with increasing the sulfur concentration in leaching solution. All the solutions tended the balance after 8 days. The $\mathrm{pH}$ value of the solutions after 10 days depending on sulfur concentration $(0.1 ; 0.2 ; 0.3 ; 0.4 \mathrm{~g})$ were $2.15,1.47,1.44$ and 1.43 respectively.

The leaching effect of mixed bacteria was the most significant in variant with sulfur concentration of $0.2 \mathrm{~g}$. The leaching rates of heavy metals such as $\mathrm{Pb}, \mathrm{Cd}, \mathrm{Cu}$ and $\mathrm{Ni}$ of the same concentration were $74.72 \%$, $81.54 \%, 70.46 \%$, and $77.35 \%$ respectively. There was no significant increase in leaching rates of heavy metals when sulfur concentration exceeded $0.2 \mathrm{~g}$. The leaching rates of $\mathrm{Ni}$ declined slightly. The result indicated in variants with $\mathrm{FeSO}_{4} .7 \mathrm{H}_{2} \mathrm{O}$ and sulfur concentration of $0.2 \mathrm{~g}$ the leaching effect of T.f. and T.t. in mixed condition may be quite significant and economic, and the heavy metal contents meet with the National agricultural standards (Figure 4). 


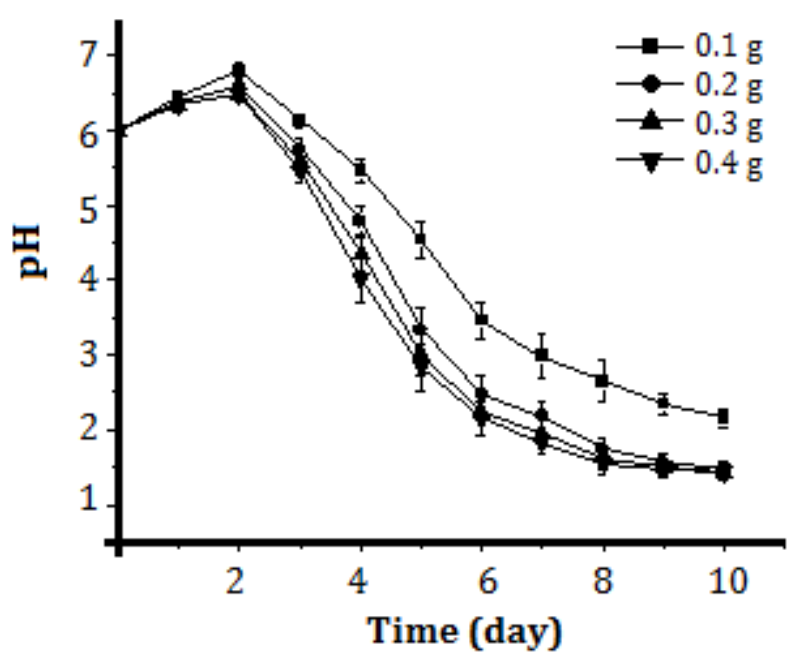

Figure 3. Effect of sulfur concentration on $\mathrm{pH}$ of leaching solutions

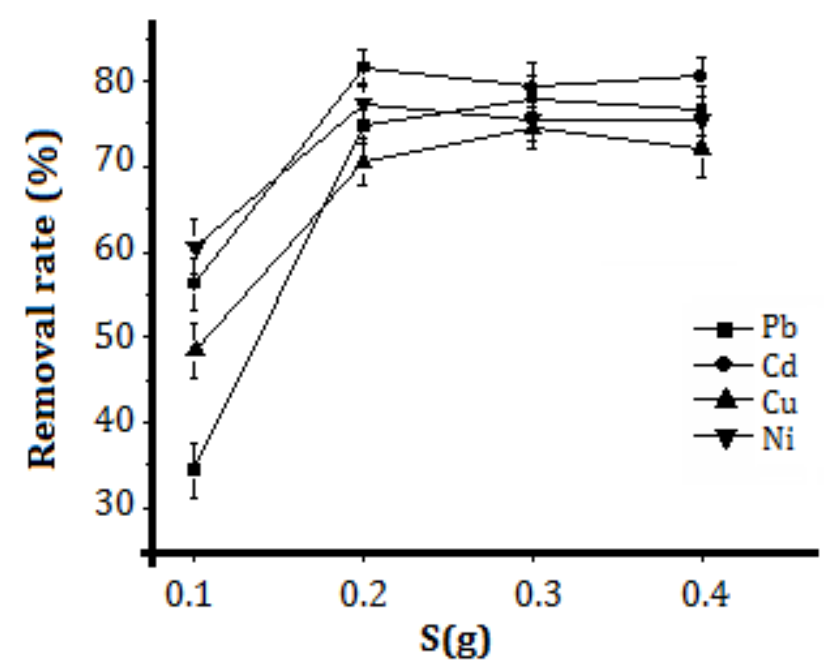

Figure 4. Effect of sulfur concentration on the leaching efficiency of heavy metals

\section{Effect of different $\mathrm{pH}$ conditions on the leaching efficiency of mixed bacteria}

At the beginning, the $\mathrm{pH}$ value of all solutions increased in small rate then decreased significantly up to the minimum $\mathrm{pH}$ value of about 1.5 (Figure 5). In case the $\mathrm{pH}$ value exceeded 2.0 the leaching rates of heavy metals were relatively high. However, in case the $\mathrm{pH}$ value was lower than 2.0 the bio-chemical reaction was suppressed by increased content of acids, and bio-leaching process was absent. When the initial $\mathrm{pH}$ values were 6.0, 5.0, 4.0 and 3.0, there were no significant differences between the leaching rates of heavy metals. The result indicated that the $\mathrm{pH}$ value of bio-leaching solution should not be rather high as the bio-leaching process generated acid and increased content of acid in the initial stage may facilitate the bio-leaching reaction. The $\mathrm{pH}$ value declined to 1.5 at the end of the process. Most of heavy metals separated out of solid sludge into the solution and concentrated in solid-liquid fraction (Figure 6).

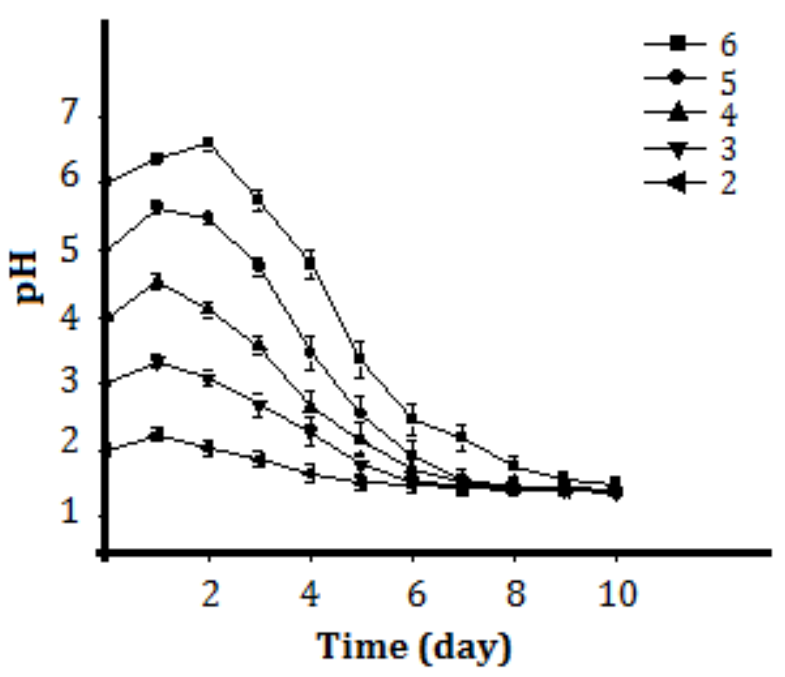

Figure 5. Effect of $\mathrm{pH}$ value on the leaching solutions

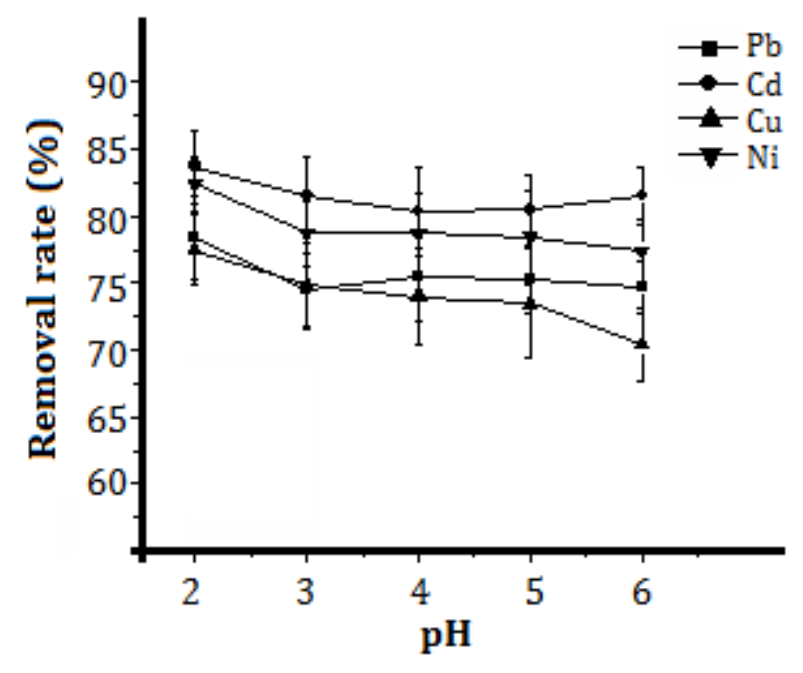

Figure 6. Effect of initial pH on the leaching efficiency of heavy metals

\section{Changes in nutrient matters content while bio-leaching process}

Leaching process generated acids and the $\mathrm{pH}$ value declined to low parameters. Some nutrient matters in sludge dissolved into solution along with heavy metals. The nutrient matters are absorbed by T.f. and T.t. from the sludge during their propagation that resulted as the nutrient matters losses. Moreover, some nutrient matters losses connected with microbial nitrification that is restricted in acidity condition and some heterotrophic microorganism denitrified nitrogen into $\mathrm{NH}_{4}{ }^{+} \mathrm{N}$ (Benmoussa et al., 1998). After 10 days the losses of nitrogen was $1.77 \mathrm{~g} \mathrm{~kg}^{-1}$, and the_rate of losses was $15.40 \%$ (Table 3). 
Table 3. Content of nutrient matters in sludge $\left(\mathrm{g} \mathrm{kg}^{-1}\right)$

\begin{tabular}{lcccc}
\hline Sludge & Organic Matter & $\mathrm{N}_{\text {total }}$ & $\mathrm{P}_{\text {total }}$ & $\mathrm{K}_{\text {total }}$ \\
\hline Before Leach & 435.61 & 11.49 & 13.24 & 4.8 \\
After Leach & 396.92 & 9.72 & 8.15 & 4.13 \\
National Primary Standard of China & $>40$ & $>2.0$ & $>1.0$ & - \\
\hline
\end{tabular}

As to the losses of phosphorus in leaching solution, phosphates in not dissolvable stage and some phosphorus compounds were changed into free phosphate ions under acid condition. Relevant researches showed that epicyte protein of T.t. cells needed more phosphorus than other microorganisms (Varela et al., 1998). After 10 days the losses of phosphorus was 5.09 g.kg-1 and the rate of losses was $38.44 \%$.

The losses of potassium were not so high. Most potassium compounds were soluble so potassium in sludge was not affected in such rate by the leaching process. And potassium in solid sludge is not solved within low $\mathrm{pH}$ condition that resulted low rate of losses during bio-leaching process. After 10 days the losses of potassium was $0.67 \mathrm{~g} . \mathrm{kg}^{-1}$, and the rate of losses was $13.96 \%$.

The losses of organic matter during the leaching were also not so high. In the experiment, two types of autotrophic organisms conducted the bio-leaching process. Therefore, the losses of organic matter during the leaching process connected with another heterotrophic microorganism. The results showed that humic substance combined with bivalent heavy metals and transferred from sludge to bio-leaching liquid under acidic condition (Fournier et al., 1998). After 10 days the losses of organic matter was $38.69{\mathrm{~g} . \mathrm{kg}^{-1}}^{-1}$ and the rate of losses was $8.88 \%$.

According to the secondary report on soil characteristics in China, N, P, K and organic matter contents exceeded the standards: the organic matter, $\mathrm{N}$, and $\mathrm{P}$ contents were 10, 5 and 8 times higher in comparison with the standards, respectively. Furthermore, the heavy metal contents within the National Primary Standard of China. Therefore, bio-leaching of sludge is the possible_agricultural treatment for increasing the value of the land with low content of the nutrients.

\section{Concentration of heavy metals depending on bio-leaching process}

The concentration of all heavy metals in sludge declined after bio-leaching process. Residual form (T5) was defined in sludge in high concentration due to its chemical stability. The sum of T1 and T2 forms for defining the mobility and the sum of T1, T2 and T3 forms for ecological availability assessment of heavy metals were used. The percentages of $\mathrm{T} 1, \mathrm{~T} 2$ and $\mathrm{T} 3$ forms of $\mathrm{Pb}, \mathrm{Cd}, \mathrm{Cu}$ and $\mathrm{Ni}$ were $28.12 \%, 23.65 \%, 23.13 \%$ and $24.34 \%$, respectively. The above results point to their weak mobility and low availability that suggests low potential ecological risk (Table 4).

Table 4. Content of heavy metals in sludge depending on bio-leaching process (mg kg-1)

\begin{tabular}{lcccccccc}
\hline & \multicolumn{2}{c}{$\mathrm{Pb}$} & \multicolumn{2}{c}{$\mathrm{Cd}$} & \multicolumn{2}{c}{$\mathrm{Cu}$} & \multicolumn{2}{c}{$\mathrm{Ni}$} \\
\cline { 2 - 8 } Heavy metals & $\begin{array}{c}\text { before } \\
\text { bio- } \\
\text { leaching }\end{array}$ & $\begin{array}{c}\text { after } \\
\text { bio- } \\
\text { leaching }\end{array}$ & $\begin{array}{c}\text { before } \\
\text { bio- } \\
\text { leaching }\end{array}$ & $\begin{array}{c}\text { after } \\
\text { bio- } \\
\text { leaching }\end{array}$ & $\begin{array}{c}\text { before } \\
\text { bio- } \\
\text { leaching }\end{array}$ & $\begin{array}{c}\text { after } \\
\text { bio- } \\
\text { leaching }\end{array}$ & $\begin{array}{c}\text { before } \\
\text { bio- } \\
\text { leaching }\end{array}$ & $\begin{array}{c}\text { after } \\
\text { bio- } \\
\text { leaching }\end{array}$ \\
\hline Exchangeable form (T1) & 2.10 & 1.03 & 0.90 & 0.19 & 2.78 & 2.85 & 25.81 & 4.26 \\
Carbonate bound form (T2) & 6.20 & 0.72 & 1.80 & - & 8.69 & 1.31 & 17.49 & 1.94 \\
Oxidable form (T3) & 9.01 & 1.45 & 1.70 & 0.16 & 1.47 & 2.37 & 30.26 & 2.53 \\
Organic bound form (T4) & 6.89 & 0.82 & 1.0 & 0.16 & 45.31 & 1.17 & 18.37 & 4.47 \\
Residual form (T5) & 20.80 & 7.36 & 2.60 & 0.97 & 37.32 & 20.53 & 66.42 & 22.67 \\
Total & 45.00 & 11.38 & 8.00 & 1.48 & 95.57 & 28.23 & 158.35 & 35.87 \\
\hline
\end{tabular}

Ecological risk assessment of heavy metals concentration in sludge

The sum of T1, T2, T3 and T4 forms equals to measured value that is the assessment basis for Index of Geoaccumulation $\left(\mathrm{I}_{\mathrm{geo}}\right)$ and Potential Ecological Risk Index $\left(\mathrm{E}_{\mathrm{i}}\right)$. Before implementing bio-leaching, pollution with $\mathrm{Cd}$ was assessed as $\mathrm{I}_{\text {geo }}=5$ in comparison with $\mathrm{I}_{\text {geo }}=4.17$ that meant high potential ecological risk. Nevertheless, the pollution with other heavy metals did not cause any potential risk. However, the potential ecological risk caused by pollution with $\mathrm{Cd}$ diminished to moderate grade of contamination after implementing bio-leaching as 1 , while the $I_{\text {geo }}$ of other heavy metals declined to uncontaminated stage $\left(\mathrm{I}_{\mathrm{geo}}<1\right)$. 
Table 5. Geo-Accumulation Index and Potential Ecological Risk Index of heavy metals in sludge

\begin{tabular}{|c|c|c|c|c|c|c|c|c|c|}
\hline \multirow{2}{*}{ Metals } & \multicolumn{2}{|c|}{ Before bio-leaching } & \multicolumn{2}{|c|}{ After bio-leaching } & \multirow{2}{*}{ Metals } & \multicolumn{2}{|c|}{ Before bio- leaching } & \multicolumn{2}{|c|}{ After bio- leaching } \\
\hline & \multicolumn{2}{|c|}{ Igeo $_{\text {grades }}$} & \multicolumn{2}{|c|}{ Igeo grades } & & $E_{\mathrm{i}}$ & Risk & $\mathrm{E}_{\mathrm{i}}$ & Risk \\
\hline $\mathrm{Pb}$ & -1.12 & 0 & -3.71 & 0 & $\mathrm{~Pb}$ & 3.46 & Low & 0.57 & Low \\
\hline $\mathrm{Cd}$ & 4.17 & 5 & 0.77 & 1 & $\mathrm{Cd}$ & 810 & High & 76.5 & Middle \\
\hline $\mathrm{Cu}$ & 0.15 & 1 & -2.77 & 0 & $\mathrm{Cu}$ & 8.32 & Low & 1.1 & Low \\
\hline \multirow[t]{2}{*}{$\mathrm{Ni}$} & 0.62 & 1 & -2.18 & 0 & $\mathrm{Ni}$ & 11.49 & Low & 1.65 & Low \\
\hline & & & & & RI & 833.27 & High & 79.82 & Low \\
\hline
\end{tabular}

The toxicity coefficient $\left(\mathrm{T}_{\mathrm{i}}\right)$ of heavy metals is used to evaluate their harmful effect on humans and ecological environment, and is characterized by T1, T2, T3 and T4 parameters. Potential Ecological Risk Index is calculated based on $\mathrm{T}_{\mathrm{i}}$ and reflects the sensitivity of biological organism to heavy metals. Therefore, for assessment comprehensive potential risk (RI) is used as well (Liu et al., 2009). RI assessment also defined that the level of pollution with $C d$ was very high $\left(E_{i}=810\right)$ while the pollution with other heavy metals was assessed by low risk parameters. After bio-leaching RI parameter was reduced to 76.5 and assessed as middle potential ecological risk index. The comprehensive potential risk reduced to the grade of low potential risk that confirmed the significant reduction of ecological risk. After bio-leaching, the concentration of all heavy metals in sludge meets with the National Agricultural Sludge Quality Standard of China (GB42841984).

\section{Conclusion}

- From the point of view of economy and efficiency the optimal concentration of $\mathrm{FeSO}_{4} \cdot 7 \mathrm{H}_{2} \mathrm{O}$ and sulfur for bio-leaching process was $0.2 \mathrm{~g}$. The leaching rates of heavy metals such as $\mathrm{Pb}, \mathrm{Cd}, \mathrm{Cu}$ and $\mathrm{Ni}$ of the same concentration were $74.72 \%, 81.54 \%, 70.46 \%$, and $77.35 \%$ respectively. The heavy metal contents were within the National Agricultural Sludge Quality Standard of China (GB4284-1984).

- The high $\mathrm{pH}$ value facilitated the bio-leaching process. The eosin-bacteria Thiobacillus ferrooxidans (T.f) and Thiobacillus thiooxidans (T.t) acidified the leaching solution by metabolism activity and decreased $\mathrm{pH}$ value to 1.5 .

- The content of N, P, K and organic matter in sludge after bio-leaching exceeded the National Primary Standard of China that points to using the bio-leached sludge for increasing soil fertility.

- After bio-leaching, the potential ecological risk of heavy metals in sludge on the basis of parameters of geo-accumulation index and potential ecological risk index was reduced from the grades of high and middle to low risk.

\section{Acknowledgments}

This work was supported by the Project № 948 of the Ministry of Agriculture of China (No. 2013-Z73) and Fundamental Researches Fund of the Russian Federation No. 414611048. We appreciate assistance of Mr. Gangliang Tang to the experiment.

\section{References}

Babel, S., Dacera, D.M., 2006. Heavy metal removal from contaminated sludge for land application: A review. Waste Management 26(9): 988-1004.

Benmoussa, H., Tyagi, R.D., Campbell, P.G.C., 1998. Simultaneous sewage sludge digestion and metal leaching using an internal loop reactor: effect of suspended solids concentration. Water Research 32 (8): 2373-2390.

Brown, M. J., Lester, J.N., 1979. Metal removal in activated sludge: the role of bacterial extracellular polymers. Water Research 13(9): 817-837.

Li, C., Zhou, L., Wang S., 2008.B ioleaching of heavy metals from municipal sludge by the co-inoculation of two acidophilic Thiobacillus. Acta Scientiae Circumstantiae 28(6): 1155-1160 [in Chinese].

Dai, L., Ren, J., Tao, L., Li, H., 2012. Effects of sewage sludge application on soil and physiological property of Triticum Aestivum. Agro-Environment Science 31(2): 362-368. [in Chinese].

Fournier, D., Lemieux, R., Couillard, D., 1998.Essential interactions between Thiobacillus ferrooxidansand heterotrophic microorganisms during a wastewater sludge bioleaching process. Environmental Pollution 101(2): 303-309. 
González Benito, G., Osorio, G., Bonilla, D., 1995. Biological sulphur removal by thiobacillus thiooxidans in fine coal coming from a flotation washing plant. Coal Science and Technology 24: 1745-1748.

Hakanson, L. 1980. An ecological risk index for aquatic pollution control. A sedimentological approach. Water Research 14(8): 975-1001.

Hunsom, M., Pruksathorn, K., Damronglerd, S., Vergnes, H., Duverneuil, P., 2005. Electrochemical treatment of heavy metals $\left(\mathrm{Cu}^{2+}, \mathrm{Cr}^{6+}, \mathrm{Ni}^{2+}\right)$ from industrial effluent and modeling of copper reduction. Water Research 39(4): 610616.

Jakobsen, M.R., Fritt-Rasmussen, J., Nielsen, S., Ottosen, L.M. 2004. Electrodialytic removal of cadmium from wastewater sludge. Journal of Hazardous Materials 106(2-3): 127-132.

Kaminari, N.M.S., Schultz, D.R., Ponte, M.J.J.S., Ponte, H.A., Marino, C.E.B., Neto, A.C., 2007. Heavy metals recovery from industrial wastewater using Taguchi method. Chemical Engineering Journal 126(2-3): 139-146.

Lester, J.N., Sterritt, R.M., Kirk, P.W.W., 1983. Significance and behaviour of heavy metals in waste water treatment processes II. Sludge treatment and disposal. Science of The Total Environment 30: 45-83.

Liu, C., Shao, S.G., Fan, C.X., 2014. Pollution status and risk assessment of heavy metals in the sediment of the highly polluted confluence area of the Lake Chaohu. China Environmental Science 34(4): 1031-1037. [in Chinese]

Liu, J.Y., Sun, Y.Y., Xu, Y.B., 2009. Heavy metal characteristics in sewage sludge and its potential ecological risk assessment for agriculture implementing in Guangzhou. Acta Scientiae Circumstantiae 29(12): 2545-2556. [in Chinese]

Liu, Y.F., 2014. Experimental study on sludge drying and co-combustion with coal in pulverized coal power industrial boiler. McS Thesis, Zhejiang University, China. [in Chinese]

Lombardi, A.T., Garcia, Jr.O., 2002. Biological leaching of Mn, Al, Zn, Cu and Ti in an anaerobic sewage sludge effectuated by Thiobacillus ferrooxidans and its effect on metal partitioning. Water Research 36(13): 3193-3202.

Muller, G., 1969. Index of geoaccumulation in sediments of the Rhine River. Geojournal 2(3): 108-118.

Pansu, M., Gautheyrou, J., 2006. Handbook of Soil Analysis: Mineralogical, Organic and Inorganic Methods. SpringerVerlag Berlin Heidelberg. 993 p.

Pathak, A., Dastidar, M.G., Sreekrishnan, T.R., 2009a. Bioleaching of heavy metals from sewage sludge: A review. Journal of Environmental Management 90(8): 2343-2353.

Pathak, A., Dastidar, M.G., Sreekrishnan, T.R., 2009b. Bioleaching of heavy metals from sewage sludge by indigenous iron-oxidizing microorganisms using ammonium ferrous sulfate and ferrous sulfate as energy sources: A comparative study. Journal of Hazardous Materials 171(1-3): 273-278.

Peng, G., Tian, G., Liu, J., Bao, Q., Zang, L., 2011. Removal of heavy metals from sewage sludge with a combination of bioleaching and electrokinetic remediation technology. Desalination 271(1-3): 100-104.

Shen, L., Zhang, T.P., Jia, X.S., 2005. Removal of heavy metals contained in sewage sludges by using Thiobacillus ferrooxidans and Thiobacillus thiooxidans. Acta Scientiarum Naturalium Universitatis Sunyatseni 44(2): 111-116. [in Chinese]

Shen, R.Y., Luo, Y.M., Zhang, G.Y., Li, Z.G., Teng, Y. 2007. Effect of municipal sludge on the accumulation of organic pollutants in different plant-soil systems. Journal of Agro-Environment Science 26(2): 651-657. [in Chinese]

Shi, W., Liu, C., Ding, D., Lei, Z., Yang, Y., Feng, C., Zhang, Z., 2013. Immobilization of heavy metals in sewage sludge by using subcritical water technology. Bioresource Technology 137: 18-24.

Sreekrishnan, T.R., Tyagi, R.D., 1996. Comparative study of the cost of the heavy metals leaching from sewage sludge. Process Biochemistry 31(1): 31-41.

Tessier, A., Campbell, P.G.C., Bisson, M., 1979. Sequential extraction procedure for the speciation of particulate trace metals. Analytical Chemistry 51(7): 844-851.

Varela, P., Levican, G., Rivera, F., Jerez, C.A., 1998. Immunological strategy to monitor In situ the phosphate starvation state in Thiobacillus ferrooxidans. Applied and Environmental Microbiology 64(12): 4990-4993.

Wang, D.Q., 2004. Study on heavy metal removal from urban sewage sludge and utilization. PhD thesis, Chongqing University, Chongqing, China. [in Chinese]

Wang, H.R., Yu, P.P., Han, J.X., Zhao, B., Huang, B.C., Zhen, X.J., 2014. Survey of treatment technology of wasted water and sewage sludge in Zhejiang province. Energy Environmental Protection 28(3): 1-3. [in Chinese]

Yu, Y.J., Hu, L.K., Yang, Y., 2010. Pollution characteristics and ecological risk assessment of heavy metals in arable soils of typical river basin. Research of Environmental Science 23(12): 1523-1527. [in Chinese]

Zhou, S.G., Zhou, L.X., Huang, H.Z., 2002. Removal of heavy metals from sewage sludge by bioleaching. Acta Ecologica Sinica 22 (1): 125-133. [in Chinese]

Zhu, Y., Zeng, G., Zhang, P., Zhang, C., Ren, M., Zhang, J., Chen, M., 2013. Feasibility of bioleaching combined with Fentonlike reaction to remove heavy metals from sewage sludge. Bioresource Technology 142: 530-534. 